\title{
SANTRI BERDIKARI: SEBUAH UPAYA MEWUJUDKAN SANTRI YANG SEHAT DAN MANDIRI
}

\author{
Veni Fatmawati ${ }^{1)}$, Tri Winarsih ${ }^{2)}$, Yayuk Setyowati ${ }^{3}$ \\ ${ }^{1)}$ veni_fatma@yahoo.co.id, ${ }^{2)}$ triwinarsih@unisayogya.ac.id, \\ 3)ayu.aisyiyah@unisayigya.ac.id \\ ${ }^{1)}$ Program Studi di S1 Fisioterapi Universitas 'Asyiyah Yogyakarta, ${ }^{2)}$ Program \\ Studi S1 Psikologi Universitas 'Asyiyah Yogyakarta, ${ }^{3)}$ Program Studi S1 \\ Manajemen Universitas 'Asyiyah Yogyakarta
}

\begin{abstract}
ABSTRAK
Mitra kegiatan PKM ini adalah Pondok Pesantren PUTRI Al Imdad Kauman Wijirejo Pandak Kabupaten Bantul. Tujuan dari program PKM ini adalah untuk membantu mitra dalam mewujudkan santri yang sehat dan mandiri.

Oleh karena itu, solusi yang diberikan adalah: (1) Memberikan penyuluhan dan edukasi tentang pola hidup sehat kepada santri (2) Melakukan asesmen untuk mengidentifikasi minat dan bakat santri, (3) Memberikan pelatihan membuat kerajinan tangan (handmade) (4) Memberikan pelatihan marketing online kepada santri agar bisa memasarkan produk yang dihasilkan, (5) Mengajarkan kewirausahaan (entrepreneurship) kepada santri, (6) Memberikan pelatihan pembukuan kepada santri., (7) Mengajak santri berkunjung ke pusat-pusat industri kerajinan tangan. Berdasarkan Hasil evaluasi menunjukkan bahwa adanya antuisme santri dalam mengikuti setiap rangkaian program kegiatan yang TIM berikan. Antusiame ini menunjukkan bahwa adanya dorongan yang kuat dari dalam diri santri untuk menjadi sehat dan belajar mandiri.
\end{abstract}

Kata kunci; Santri, Berdikari, Sehat, Mandiri.

\section{PENDAHULUAN}

Sehat dan mampu berdiri diatas kaki sendiri merupakan sebuah kebanggaan dan pastinya ingin dimiliki oleh setiap orang tampa terkecuali santri yang hidup asrama pondok pesantren. Karena dengan sehat dan kemandirian ini manusia akan lebih bermartabat. Memiliki tubuh yang sehat dan mandiri merupakan kebututuhan setiap manusia. Dengan badan yang sehat, akal akan mampu berpikir dengan jernih dan dengan kemandirian manusia akan mampu berdikari membangun eksistensi. Sebagaimana yang dikemukakan oleh Suryanto (2011) bahwa tubuh yang sehat merupakan faktor yang sangat penting, karena 
apabila tubuh tidak sehat segala aktivitas akan terganggu, sedangkan apabila memiliki tubuh sehat segala aktivitas dapat dikerjakan dengan lancar dan dapat menikmati hidup dengan senang hati (bahagia).

Secara teori, kemandirian dapat didefinisikan sebagai sikap yang memungkinkan seseorang untuk bertindak dan melakukan sesuatu atas dorongan sendiri dan untuk kebutuhannya sendiri tanpa bantuan dari orang lain, mampu berpikir dan bertindak kreatif dan penuh inisiatif, mampu mempengaruhi lingkungan, mempunyai rasa percaya diri dan memperoleh kepuasan dari usahanya tersebut. Selain itu, dalam kamus psikologi, kemandirian berasal dari kata independence yang diartikan sebagai suatu kondisi dimana seseorang tidak bergantung pada orang lain dalam menentukan keputusan yang disertai dengan sikap percaya diri.

Kemandirian seperti inilah yang juga diharapkan oleh para santri yang ada di Pondok Pesantren Putri Al Imdad Kauman Wijirejo Pandak Kabupaten Bantul. Kemandirian tidak akan muncul begitu saja, kemandirian harus dilatih dan untuk membentuk santri yang mandiri juga membutuhkan waktu dan proses yang tidak sebentar. Sebagaimana yang dikemukakan oleh Martinis Yamin (2013, dalam Rantina: 2015) bahwa kemandirian merupakan kemampuan hidup yang utama dan salah satu kebutuhan sejak awal usianya. Membentuk anak usia dini sebagai pribadi yang mandiri memerlukan proses yang dilakukan secara bertahap. Oleh sebab itu, untuk mewujudkan santri yang mandiri diperlukan wadah dan juga SDM (sumber daya manusia) yang mampu melatih, mampu membentuk dan mampu menularkan ide-ide atau gagasan-gagasan kepada santri sehingga nantinya santri-santri tersebut dapat tumbuh menjadi santri-santri berdikari, kreatif, inovatif dan tentunya mandiri.

Sebagai informasi, santri-santri Pondok Pesantren Putri Al Imdad Kauman Wijirejo Pandak Kabupaten Bantul. ini adalah santri-santri yang berasal dari keluarga dengan ekonomi lemah. Bahkan banyak diantara mereka adalah anak yatim-piatu sehingga biaya pendidikan mereka di pesantren disubsidi oleh pesantren dan para dermawan. Namun karena banyak keterbatasan dari aspek pembiayaan dan Sumber Daya Manusia yang ada di Pondok Pesantren Putri Al 
Imdad Kauman Wijirejo Pandak Kabupaten Bantul. ini, Maka kebutuhan santri untuk menjadi santri yang berdikari sulit terwujud.

Pondok Pesantren Al-Imdad adalah salah satu pondok Pesantren Salafi yang berada di daerah Pedesaan, Pondok Pesantren ini didirikan oleh KH Humam Bajuri pada tahun 1980. Pondok Pesantren Al-Imdad terletak di dusun Kauman RT 01 RW 016 desa Wijirejo kecamatan Pandak kabupaten Bantul. Dusun ini terletak di arah barat daya kota Bantul kurang lebih $7 \mathrm{~km}$, dekat perbatasan Kabupaten Bantul dan Kulonprogo, tepatnya sebelah timur Sungai Progo kurang lebih berjarak $2 \mathrm{~km}$.

Berikut ini adalah gambaran kondisi Pondok Pesantren Putri Al Imdad Kauman Wijirejo Pandak Kabupaten Bantul.
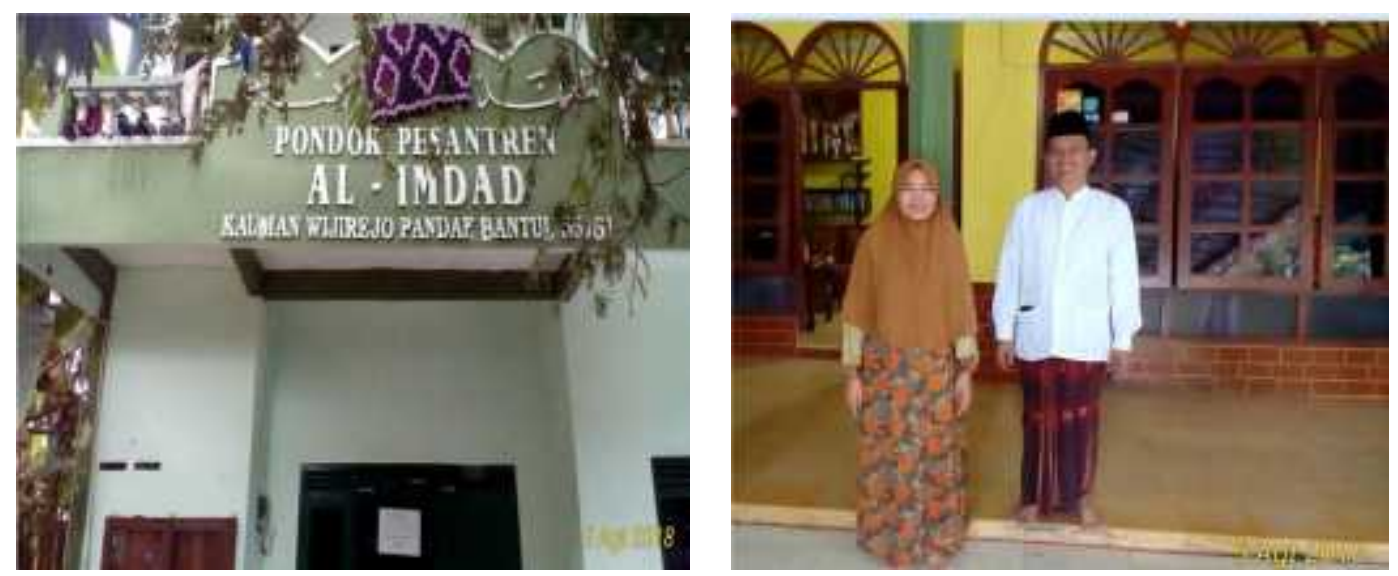

Gambar 1. Pengasuh Pondok Pesantern Putri Al Imdad
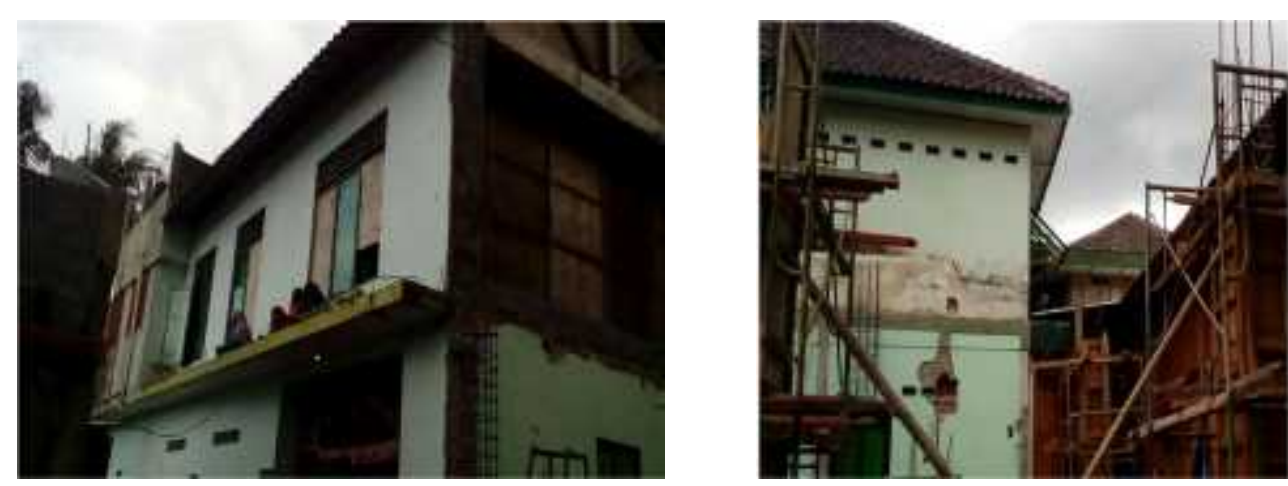

Gambar 2. Gedung Asrama dan Gedung Sekolah Pondok Pesantern Putri Al Imdad 

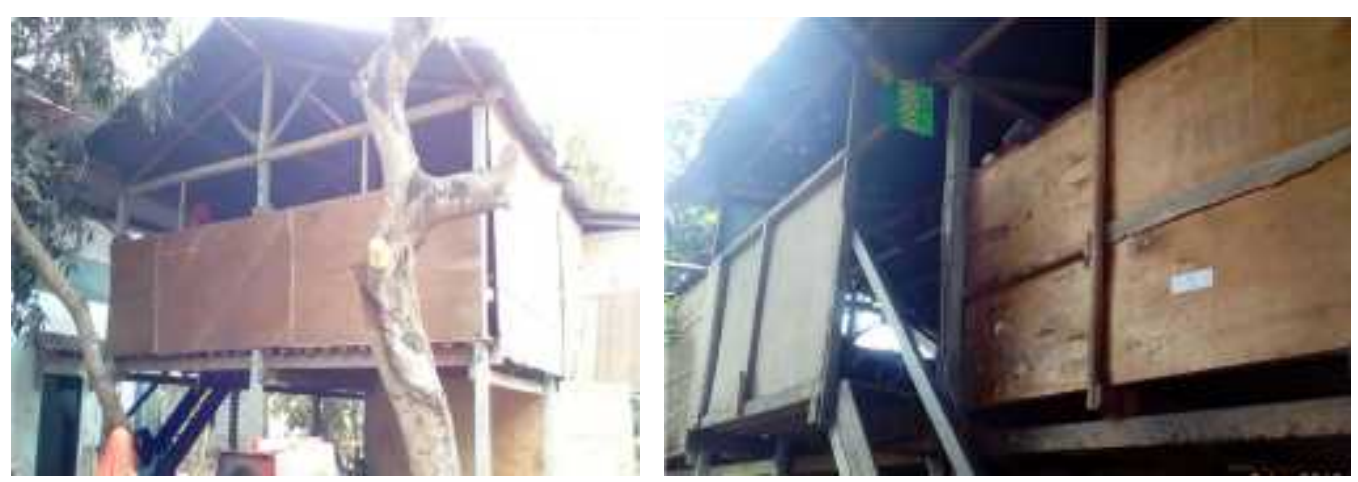

Gambar 3. Ruang Serbaguna Pondok Pesantern Putri Al Imdad
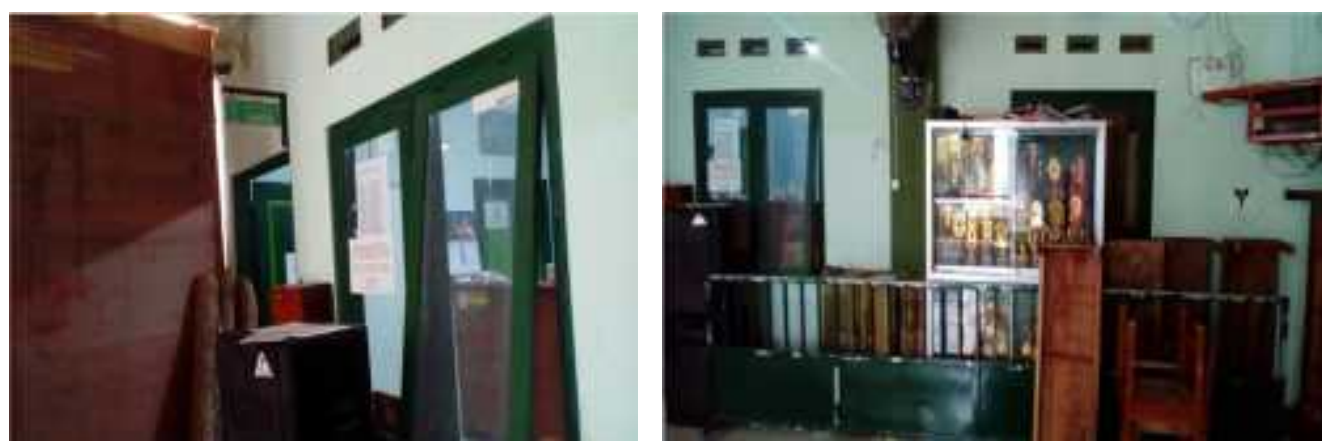

Gambar 4. Ruang Kantor Pondok Pesantern Putri Al Imdad

MITRA dalam kegiatan PKM ini adalah Pondok Pesantren Putri Al Imdad Kauman Wijirejo Pandak Kabupaten Bantul. Berdasarkan informasi yang Tim dapatkan dari Pengelola Pesantren Putri Al Imdad Bpk. Ahmad Murod. Permasalahan yang dihadapi pesatren dalam upaya mewujudkan santri berdikari (santri yang sehat dan mandiri) adalah ada pada fasilitas, sarana prasarana dan sumber daya manusia yang dimiliki oleh pesantren.

Ahmad Murod menjelaskan bahwa ada beberapa kegiatan ekstra yang diberikan di Pesantren Putri Al Imdad Kauman Wijirejo Pandak Kabupaten Bantul. Kegiatan ekstra tersebut adalah; Hadroh, seni baca qur'an, kaligrafi, olah raga, pencak silat dan life skill (menjahit).

Ahmad Murod menambahkan bahwa saat ini hanya ada satu kegiatan yang digunakan untuk menumbuhkan jiwa kewirausahaan santri putri. Kegiatan tersebut adalah 'menjahit'. Namun ekstra menjahit ini sudah berhenti sejak tahun 
2016. Berhentinya kegiatan ini disebabkan oleh dua hal; 1) Tidak ada Guru yang mengajar ekstra menjahit, 2) Padatnya aktifitas yang dilakukan oleh santri.

Kekurangan SDM (Sumber daya manusia) dan padatnya aktifitas santri menjadi salah satu alasan Pondok Pesantren Al Putri Imdad Kauman Wijirejo Pandak Kabupaten Bantul tidak memberikan kegiatan ekstra yang bisa menumbuhkan skill kewirausahaan santri. Selain dari 2 alasan diatas, alasan lain yang mendasari Pesantren Al Imdad Kauman Wijirejo Pandak Kabupaten Bantul untuk tidak memberikan pelatihan kewirausahaan pada santri Putri adalah minimnya sarana dan prasarana pesantren.

Adanya keterbatasan-keterbatasan baik dalam aspek sarpras dan SDM ini, pesantren kesulitan dalam mencari kegiatan-kegiatan yang bisa menstimulus kreatifitas para santri. Selain itu, pihak pesantren mengaku bahwa belum ada kegiatan-kegiatan pesantren yang secara spesifik berkaitan dengan peningkatan kemandirian santri. Hal ini tentunya akan semakin mempersulit para santri untuk menjadi santri yang berdikari.

Berdasarkan latar belakang dan uraian permasalahan diatas, maka solusi yang ditawarkan untuk mewujudkan santri berdikari adalah dengan cara: 1) Memberikan penyuluhan dan edukasi tentang pola hidup sehat kepada santri, 2) Melakukan asesmen untuk mengidentifikasi minat dan bakat santri., 3) Memberikan pelatihan membuat kerajinan tangan (handmade) yang sesuai dengan minat dan bakat santri, 4) Memberikan pelatihan marketing online kepada santri agar bisa memasarkan produk yang dihasilkan, 5) Memberikan pelatihan kewirausahaan (entrepreneurship) kepada santri, 6) Memberikan pelatihan pembukuan kepada santri, 7) Mengajak santri berkunjung ke pusat-pusat industri kerajinan tangan. 
Tabel 1.

Masalah dan solusi yang ditawarkan untuk mitra

\begin{tabular}{ccl}
\hline Masalah & \multicolumn{2}{c}{ Solusi } \\
\hline Mitra & 1) & $\begin{array}{l}\text { Memberikan penyuluhan dan edukasi tentang pola hidup sehat } \\
\text { kepada santri. }\end{array}$ \\
memiliki & 2) & Melakukan asesmen untuk mengidentifikasi minat dan bakat santri. \\
keterbatasan & 3) & Memberikan pelatihan membuat kerajinan tangan (handmade) \\
skill, ide dan & & yang sesuai dengan minat dan bakat santri. \\
gagasan & 4) & Memberikan pelatihan marketing online kepada santri. agar bisa \\
sehingga & & memasarkan produk yang dihasilkan, \\
belum mampu & 5) & Memberikan pelatihan kewirausahaan (entrepreneurship) kepada \\
mewujudkan & & santri. \\
santri & 6) & Memberikan pelatihan pembukuan kepada santri. \\
berdikari. & 7) & $\begin{array}{l}\text { Mengajak santri. berkunjung ke pusat-pusat industri kerajinan } \\
\text { tangan. }\end{array}$ \\
& &
\end{tabular}

\section{METODE PELAKSANAAN}

Secara sederhana metode pelaksanaan kegiatan pengabdian masyarakat untuk mewujudkan santri berdikari ini dapat digambarkan melalui diagram alir sebagai berikut:

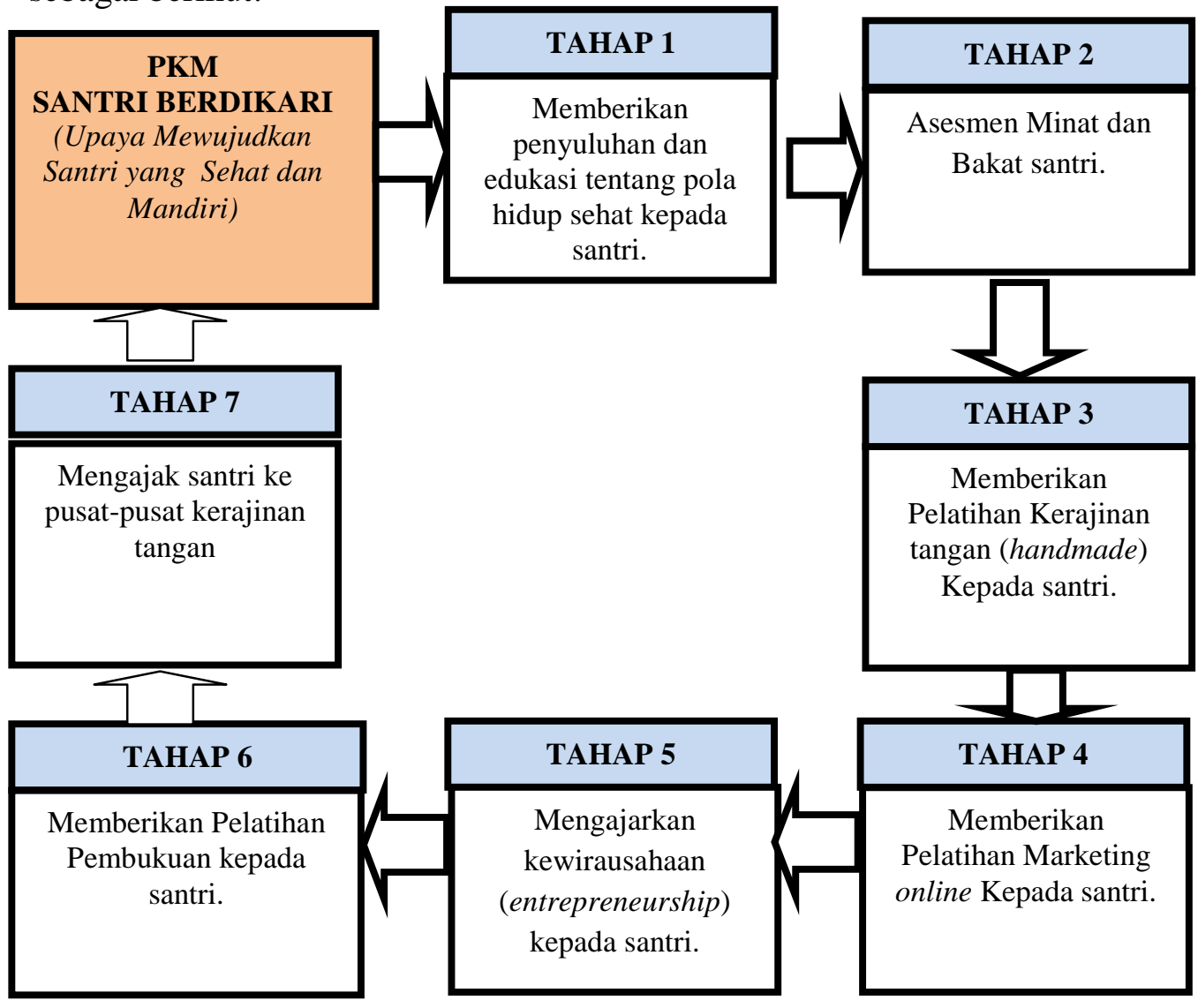

Gambar 5. Alur Metode Pelaksanaan Pengabdian 


\section{1) Memberikan Penyuluhan dan Edukasi Tentang Pola Hidup Sehat Kepada Santri}

Upaya mewujudkan santri yang sehat dan mandiri akan diawali dengan memberikan penyuluhan dan edukasi tentang pola hidup sehat dan mengadakan pemeriksaan kesehatan Santri. Seperti mengedukasi cara cuci tangan yang benar, menjaga kebersihan lingkungan pesantren dan lain sebagainya. Hal ini bertujuan agar santri nantinya terbiasa dengan pola hidup sehat dan bersih.

\section{2) Melakukan Asesmen untuk Mengidentifikasi Minat dan Bakat Santri}

Psikotes minat bakat akan diberikan kepada Santri. Hal ini bertujuan untuk mengetahui bakat apa yang ada pada diri Santri. Dengan mengetahui bakat tersebut akan semakin mempermudah Tim dalam memilih dan mengajarkan kreatifitas kepada mereka.

Minat bakat Santri ini akan diasesmen dengan menggunakan alat tes RMIB (Rothwell Miller Interest Blank). Tes ini disusun dengan tujuan untuk mengukur interest seseorang berdasarkan sikap seseorang terhadap suatu pekerjaan. Hal yang didasarkan atas ide-ide stereotype terhadap pekerjaan yang bersangkutan. Pemikiran yang mendasari pembentukan tes ini adalah bahwa setiap orang memiliki konsep-konsep stereotype terhadap jenis-jenis pekerjaan yang tersedia atau yang disediakan oleh masyarakat, kemudian memilih pekerjaan yang sesuai dengan ide-ide tersebut, meskipun terdapat juga stereotype yang tidak berdasarkan ide tertentu atau tidak ada hubungannya sama sekali dengan pekerjaan yang dimaksud (Faiz: 2016).

\section{3) Memberikan Pelatihan Kerajinan Tangan (handmade) Kepada Santri}

Setelah Santri diberikan psikotes untuk mengetahui minat dan bakat mereka. Maka langkah kedua dalam kegiatan PKM ini adalah memberikan pelatihan kerajinan tangan (handmade) kepada Santri yang sesuai dengan minat dan bakatnya. Artinya jenis pelatihan handmade yang akan diberikan tergantung dari hasil tes minat dan bakat Santri. Namun sebagai gambaran, ada beberapa jenis kerajinan tangan yang mungkin bisa diberikan kepada Santri, seperti: 
membuat gantungan kunci, membuat kipas dari bahan bambu, membuat tempat tisu dan lain sebagainya.

\section{4) Memberikan Pelatihan Marketing Online Kepada Santri}

Pemberian pelatihan marketing ini diberikan agar Santri dapat mempromosikan dan memasarkan hasil kerajinan tangan mereka kepada masyarakat luas. Sehingga masyarakat bisa menikmati hasil atau produk yang dihasilkan oleh Santri tersebut.

\section{5) Memberikan Pelatihan Kewirausahaan Kepada Santri}

Pelatihan kewirausahaan kepada santri ini dilakukan agar Santri semakin termotivasi untuk berwirausaha. Sehingga nantinya mereka bisa menjadi pribadipribadi yang mandiri.

\section{6) Memberikan Pelatihan Pembukuan Kepada Santri.}

Pelatihan pembukuan ini diberikan agar mitra bisa membuat pembukuan terhadap hasil penjualan yang sudah mereka lakukan. Selain itu, melalui pelatihan pembukuan ini diharapkan mitra bisa membuat kalkulasi utung rugi terhadap usaha yang sudah mereka lakukan.

\section{7) Mengajak Santri Berkunjung Ke Idustri-Industri Industri Kerajinan \\ Tangan}

Langkah terakhir dalam kegiatan pengabdian ini adalah mengajak Santri berkunjung ke pusat-pusat industri kerajinan tangan yang ada di Kota Jogja dan sekitarnya, seperti: Desa Wisata Krebet sebagai pusat kerajinan kayu ukir, Kasongan sebagai pusat kerajinan gerabah dan Manding sebagai pusat kerajinan kulit. Hal ini bertujuan untuk memberikan gambaran dan wawasan kepada Santri terkait dengan industri kerajinan tangan sehingga Santri memiliki gambaran bagaimana membuat dan memasarkan produk yang akan mereka dihasilkan.

\section{HASIL DAN DISKUSI}

Secara intensif, Tim dari Universitas 'Asyiyah Yogyakarta melakukan kegiatan pengabdiaan kepada masyarakat di Pondok Putri Al Imdad Kauman Wijirejo Pandak Bantul. Hal ini dilakukan agar santri yang ada di Pondok Pesantren Putri Al Imdad tersebut bisa menjadi "Santri Berdikari“, santri yang 
sehat dan mandiri. Sehingga nantinya mereka bisa dan mampu berdiri diatas kaki mereka sendiri, memiliki kreatiftas serta mempunyai jiwa kewirausahaan yang baik.

Kegiatan PKM ini diawali dengan memberikan penyuluhan kepada santyri terkait dengan pola hidup sehat yang memang menjadi salah satu permasalahan klasik di Pesantren. Oleh sebab itu, Tim dari Universitas 'Asyiyah Yogyakarta menjadikan isu kesehatan dan kebersihan ini menjadi salah satu target sasaran dalam kegiatan pengabdian ini. Berikut ini adalah beberapa dokumentasi terkait dengan kgiatan penyuluhan di Pondok Pesantren Putri Al Imdad Bantul.
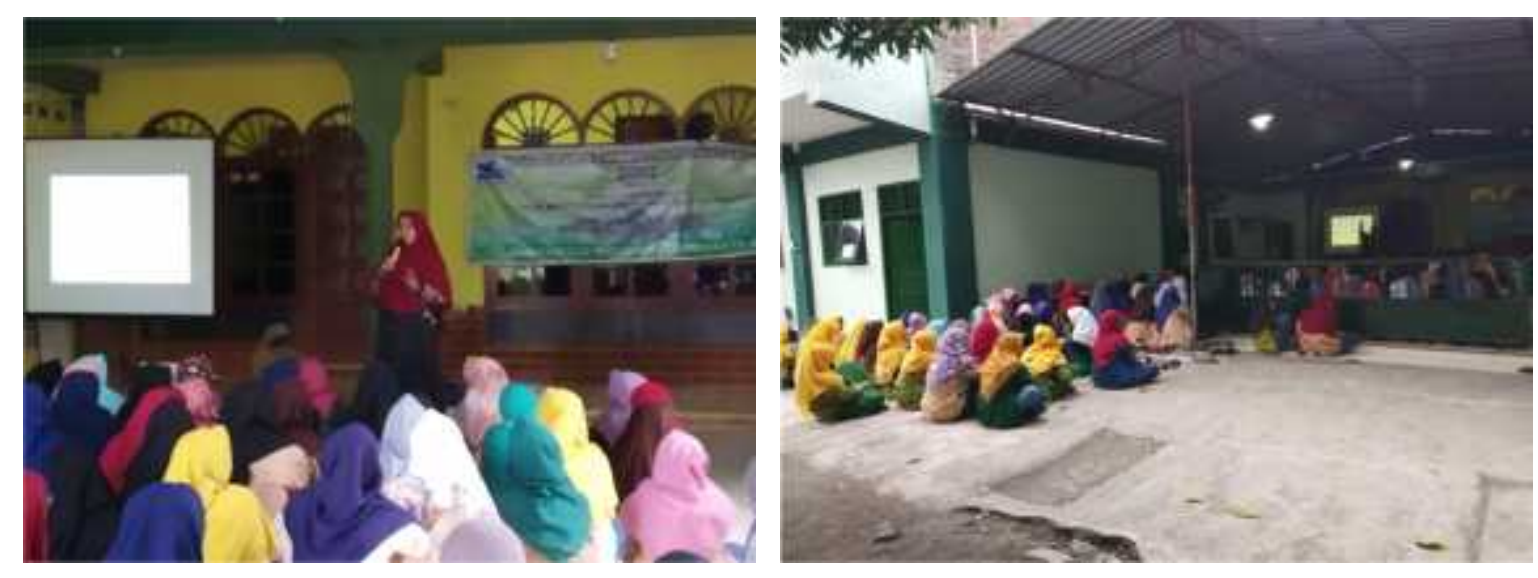

Gambar. 6.

Kegiatan penyuluhan di Pondok Pesantren Putri Al Imdad Bantul

Setelah memberikan penyuluhan tentang kesehatan dan konseling psikologis kepada para santri. Tim PKM 'UNISA juga memberikan pelatihan handmade kepada santri. Pelatihan ini bertujuan untuk mencetak generasigenerasi berdikari yang muncul dari kalangan santri. Pelatihan handmade ini dimulai dari mengenalkan beberapa jenis kerajinan tangan, cara membuat, memasarkan dan membukukan hasil penjualan handmade tersebut. Berikut ini adalah beberapa contoh dokumentasi dari kegiatan pelatihan handmade di Pondok Pesantren Putri Al Imdad. 

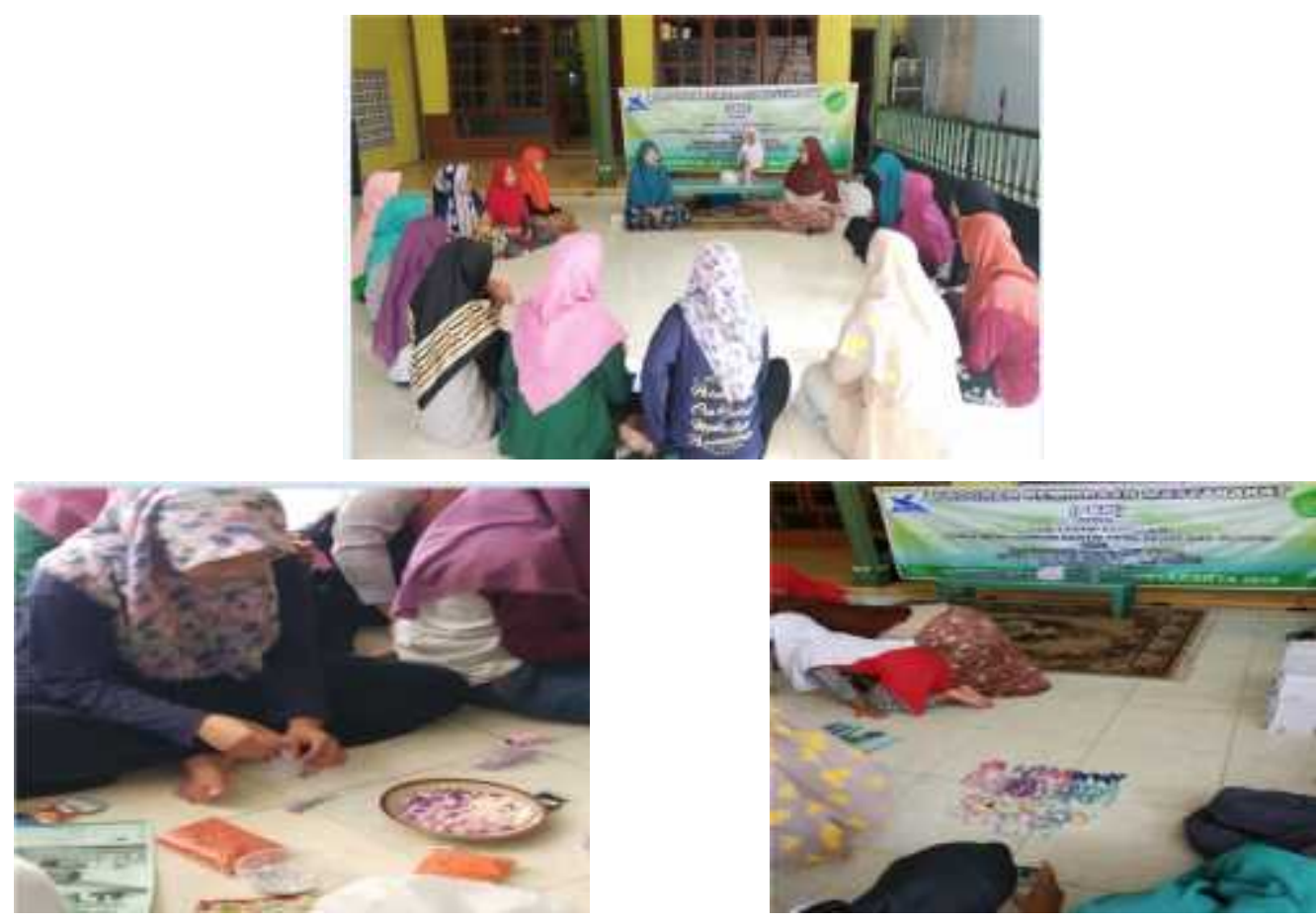

Gambar. 7.

Pelatihan handmade di Pondok Pesantren Putri Al Imdad Bantul

Berdarakan pada kegiatan-kegiatan yang sudah dilakukan di atas, maka ada beberapa rekomendasi yang Tim berikan untuk mewujudkan satri berdikari yang ada di pesantren putri Al Imdad Kauman Pandak Bantul ini. Beberapa rekomendasi tersebut adalah sebagai berikut:

1) Mengingat besarnya antusiasme santri dalam mengikuti pelatihan handamade ini, maka disarankan kepada pesantren agar terus melanjutkan program ini. Dengan demikian keinginan santri untuk menjadi santri yang mandiri dan memiliki skill yang baik dapat terwujud.

2) Berdasarkan hasil audiensi dengan santri, diketahui bahwa kesulitan mereka adalah dalam hal marketing. Untuk itu, kami merekomendasikan kepada pesantren agar memfasilitasi kebutuhan santri dalam melakukan pemasaran khususnya marekting online dengan menyediakan sarana prasarana yang dibutuhkan seperti: komputer, wifi dan lain sebagainya. 
3) Berkaitan dengan pola hidup sehat santri, maka Tim merekomendasikan kepada pesantren agar melakukan kerjasana dengan klinik kesehatan atau puskesmas setempat agar kesehatan santri bisa dikontrol dengan baik.

\section{KESIMPULAN DAN IMPLIKASI}

Mengacu kepada uraian-uraian kegiatan PKM yang sudah berjalan diatas, maka dapat diketahui bahwa kegiatan yang tim berikan cukup diminati oleh santri. Hal ini bisa dilihat dari besarnya antusiasme santri dalam mengikuti setiap kegiatan yang Tim berikan.

\section{DAFTAR PUSTAKA}

Faiz, Muhamamd Mabruri (2016) Sistem Informasi Penelusuran Minat Pekerjaan Dengan Tes The Rothwell Miller Interest Blank (RMIB). Program Studi Informatika Fakultas Komunikasi Dan Informatika Universitas Muhammadiyah Surakarta. http://eprints.ums.ac.id/41389/14/publikasi.pdf

Rantina, Mahyumi (2015). Peningkatan Kemandirian Melalui Kegiatan Pembelajaran Practical Life (Penelitian Tindakan Di TK B Negeri Pembina Kabupaten Lima Puluh Kota,Tahun 2015). Jurnal Pendidikan Usia Dini. Volume 9 Edisi 2, November 2015.

Suryanto (2011) Peranan Pola Hidup Sehat Terhadap Kebugaran Jasmani. Artikel. http://staffnew.uny.ac.id/upload/131808680/penelitian/5.+Peranan+Pola+Hi dup+Sehat+Terhadap+Kebugaran+Jasmani+(+Medikora,+Oktober+2011+). pdf. Diakses 16 april 2018. 